New Zealand Annual Review of Education (2018) 23: 5-19

DOI:

\title{
Zero-fee policy: Making tertiary education and training accessible and affordable for all?
}

\author{
Pii-Tuulia Nikula and Kay Morris Matthews \\ Eastern Institute of Technology
}

The new Labour led government implemented a zero-fee tertiary policy as part of its first 100-day plan to improve tertiary level participation in New Zealand and to reduce financial barriers. With the first cohort of eligible students enrolling in 2018, the benefits and limitations of this scheme have yet to be determined. This paper discusses the key details and the underpinning rationale of the zero-fee initiative and considers the possible impacts on participation rates, including participation for groups such as those from low socioeconomic backgrounds and Māori/Pasifika students. It is argued that the fees-free policy has the potential to enhance tertiary education participation in New Zealand. Yet, as a standalone policy it will not address all the existing barriers, especially for students from lower socio-economic backgrounds. Finally, key areas for further research are proposed to address gaps in the existing knowledge base and to indicate early trends between the new policy and changes in tertiary level participation.

Keywords: Fees free, tuition fees, New Zealand, student funding policy, tertiary education participation, socio-economic inequalities, Māori, Pasifika

\section{Introduction}

In January 2016 the Labour Party announced its 'Working Futures' plan which included a proposal for a gradual implementation of a three-year free fee entitlement targeted for new school leavers (Labour Party, 2016). The zero-fee plan was adopted by the new party leader, Jacinda Ardern, as one of the key promises in the 2017 election campaign. Following Labour's rise to power, the promise was quickly turned into government policy, providing one year of free study, extending to two years in 2021, and three years in 2024 (Labour Party, n.d.; Tertiary Education Commission, 2018b). The free tertiary level study entitlement is available for anyone who has not previously studied for more than half a year at tertiary level, covering areas such as courses at universities and institutes of technology and polytechnics (ITPS) as well as industry training and apprenticeships (Tertiary Education Commission, 2018b). This initiative aims to reverse the decline in tertiary participation seen under the previous governments ${ }^{1}$ and to reduce cost related barriers for access (Labour Party, n.d.).

${ }^{1}$ The 2006-2016 provider-based enrolment data indicate around four percent decrease in level 1 and above participation in the 16-64 year age group (Ministry of Education, 2017g, p. 4). However, participation in higherlevel qualifications (level 6 and above) has remained fairly stable over the past decade (Ministry of Education, 2017g, p. 4; Ministry of Education, 2018c, 'Participation Rate: PPN6'). 
The first cohort of students eligible for the zero-fee entitlement started in early 2018; hence limited evidence is yet available to demonstrate the impacts of this policy. This paper is one of the first attempts to discuss the details of this policy and critically evaluate it from the perspectives of tertiary education participation in general, and, of participation specifically for students from low socio-economic backgrounds as well as Māori/Pasifika students.

\section{Background: The zero-fee policy framework}

The New Zealand user-pay model for tertiary education was introduced in 1990 in the form of a $\$ 1,250$ upfront flat fee with an abatement scheme for students from low income backgrounds (Nikula, 2015). This reform and other changes in the 1990s were part of the impact of the government's neoliberal agenda of the time that affected various policy domains in the form of cuts, targeting and privatisation (Butterworth \& Tarling, 1994; Kelsey, 1995; Nikula, 2015; Starke, 2008). In 1992, the fee system was deregulated, and the abatement scheme abolished. At this point, a new universal income contingent student loan scheme was introduced to help students cover the full cost of fees and to assist towards the living costs for those ineligible for student allowances. During the 1990s, the average fee levels increased rapidly as a result of government cuts in per student funding rates. By 2000 , the average annual public provider fee reached $\$ 3,562$ (Ministry of Education, 2018b; Nikula, 2015).

From 2000, for some years fees remained relatively stable, largely explained by the then Labour Government's funding policies, such as the fee freeze and fee stabilisation schemes (Ministry of Education, 2018b; Nikula, 2015). In 2016, the average annual fee at public tertiary education providers was $\$ 5,229$ (around $\$ 3,670$ when inflation adjusted to year 2000), ranging from an average fee of $\$ 6,938$ at universities, $\$ 4,030$ at ITPs and $\$ 463$ at Wananga (Ministry of Education, 2018b). With minor eligibility restrictions, most domestic students in 2017 were eligible for the interest-free student loan scheme, including tuition fee, course cost, and living cost components. Further, a more restricted number of students were eligible for student allowances and accommodation benefits (Ministry of Education, 2017b; Ministry of Social Development, n.d.). The share of private costs of the tertiary fees (when calculated with the student loan subsidies) between 2007 and 2017 was at around 16-20 per cent, compared to 33 per cent in year 2000 (Baxter, 2012; Crawford, 2016; Ministry of Education, 2008, 2017b).

Prior to the 2017 election, the rate of private costs and related student debt was still regarded as too high by the New Zealand Labour Party. It was not the first time that Labour had argued for increased generosity in student funding in bids to attract voters. In the 1999 and 2005 election campaigns Labour promised to introduce interest-free student loans whilst the 2007 campaign promoted universal student allowances (Nikula, 2015). The zero-fee promise and the $\$ 50$ weekly increase in student allowances/student loan living components made to students during the 2017 election campaign proved popular. Once in government, the zero-fee policy was actioned almost immediately, and in contrast to many other major policy initiatives, without a general consultation process (Jones, 2018). Labour's decision to fast-track the policy to start at the beginning of 2018 also meant that relevant ministries had limited time to design the scheme and/or evaluate its fiscal and other implications (c.f. Institute of Public Administration New 
Zealand, 2018; Ministry of Education, 2017d). ${ }^{2}$ The efficient cross-agency collaboration has been mentioned as one of the key reasons behind the successful implementation in the short timeframe (Institute of Public Administration New Zealand, 2018, p. 10).

In 2018, the one-year full-time study entitlement is available for New Zealanders and most permanent residents who have not previously undertaken more than half a year of equivalent full-time tertiary education ( 0.5 EFTS or 60 credits) at Level 3 or above (New Zealand Qualifications Framework levels) in New Zealand or overseas ${ }^{3}$ (Tertiary Education Commission, 2018b). The fees-free entitlement can be used across different years to allow part-time study but cannot be 'banked'. That is, a student cannot choose to pay the first year upfront to save the free entitlement for more expensive study later in life. During the policy planning phase, the Government also decided on a fee cap of $\$ 12,000$ dollars a year, expected to impact on a small number of students enrolled in high-cost programmes, such as medicine, dentistry, and aviation (Ministry of Education, 2017c).

The annual additional cost of the zero-free policy is expected to be at around $\$ 346-\$ 374$ million between 2018/2019 and 2020/21 without provision for new enrolments ${ }^{4}$ and with around $\$ 67$ million lower annual total operating balance impact when the student loan costs are considered (Ministry of Education, 2017a, p. Table C). What was indicated in Labour's election manifesto was the implementation of the second (2021) and third (2024) year of zero-fee entitlement. The costs for this extension are yet to be formally estimated, but Labour's initial calculations set the cost of the reform at $\$ 1.2$ billion at full implementation (Small, Kirk, \& Cooke, 2017). Labour has also proposed further conditions for the second and third year eligibility, namely, that continuing eligibility for fees-free study would require students to pass at least half their courses in the previous year (Labour Party, n.d.). Just what happens next with these policy instruments, costs, and with the overall funding mechanisms remains unclear in mid-2018. Such details are yet to be officially announced.

\section{Tertiary Education Participation and the Zero-Fee Policy}

The key stated rationales behind the zero-fee policy are affordability, addressing financial barriers, and reversing the declining trends in tertiary education participation to equip New Zealanders with the advanced skills needed in future job markets (Labour Party, n.d.; Ministry of Education, 2017d). Indeed, the Ministry of Education explained the fees-free policy as "making tertiary education more affordable, removing barriers to participation (particularly for those who have not previously studied at tertiary level), and assisting more people to acquire the skills they need for work" (Ministry of Education, 2017f, p. 1).

However, elsewhere, the Ministry of Education has emphasised the difficulties in forecasting the impacts of the zero-fee policy on overall participation and in the short-term assumes that enrolment will remain at the same level (rather than decline), and increase by 1 per

\footnotetext{
2 The first 2018 round was based on a provider payment model with bulk funding to the institutions using the published programme fees and forecasted number of eligible students with any variation in these estimated numbers paid/paid back at the end of 2018 (Tertiary Education Commission, 2018a).

${ }^{3}$ There are certain residency requirements impacting on eligibility.

${ }^{4}$ Figures include both provider and industry training and related central administration costs.
} 
cent by 2020 (Ministry of Education, 2017a). To date, tertiary education providers have reported fairly stagnant enrolment trends from the first half of 2018, most universities having experienced limited, if any, movement in participation (Gerritsen, 2018; Zero-fees, 2018). A few ITPs have seen a significant growth in the number of inquiries and students (Collins, 2017), but others have reported a drop in student numbers (Harding, 2018). Full enrolment details will be available in late 2018/early 2019 for investigation. That said, the long-term impacts of this policy cannot be reliably predicted based on the first year's data due to the late policy announcement as students' decision-making process often starts at a few years before the end of high school (Leach \& Zepke, 2005).

Moreover, the link between tuition fees/affordability and overall tertiary level participation levels is less evident (Mumper \& Freeman, 2005; OECD, 2009, 2017; Usher \& Medow, 2010). For instance, the first time entry rates to an undergraduate degree in many countries relying on significant private responsibility are above the OECD average and are clearly higher than in a number of countries charging no or nominal fees (OECD, 2017, Tables B5.1 \& C3.2). In Ireland, the zero-fee policy in 1995/1996 resulted in more first year entrants in year-toyear comparisons, but the impact on overall participation was less significant. That is, in the preceding ten years prior to the introduction of the fees-free policy there was a higher increase in the participation rate than in the ten years after the policy had been in place (Ministry of Education, 2009b). The ambiguous link between overall participation rates and tuition fee policies is also evident in the New Zealand context where large increases in private costs/tuition fees in the 1990s coincided with a significant expansion in participation (Nikula, 2015; Smart, 2009). Similarly, rather than tuition fee related causes, much of the decline in enrolments witnessed since 2005 has been reported to result from a decline in certificate level course provision (Ministry of Education, 2009a, 2017b).

Hence, trying to explain participation levels by tuition fee level changes ignores the significance of other pivotal financial (e.g., student financing schemes) and non-financial factors. These include family expectations and cultural capital, students' own aspirations, perceptions and aptitudes, mediating factors such as prior school attended and prior achievement, availability of tertiary level study options, and broader contextual factors, such as demographic trends, economic cycles and available job opportunities (c.f. Boudon, 1974; Bourdieu \& Passeron, 1977; Fergusson, Horwood, \& Boden, 2008; Higgins, Vaughn, Phillips, \& Dalziel, 2008; James, 2001; Leach \& Zepke, 2005; Ministry of Education, 2009a; Perna, 2010; Smart, 2009; TEC, 2014).

The financial barriers likely to impact on tertiary education participation can be further divided into three main categories: price constraints (benefits and costs of acquiring tertiary education); liquidity constraints (availability of sufficient funds); and debt aversion (attitude towards incurring debt) (Usher, 2006). In the New Zealand context, the liquidity constraints related to tuition fees and living costs have been, at least partially, addressed by the deferred income contingent student loan scheme, including both a full tuition fee and a living cost component as well as the availability of a targeted student allowance scheme. The fairly high student loan intake ratio (around 70 per cent of all eligible students) suggests a somewhat limited debt aversion among the overall student population (Ministry of Education, 2017b). In a 2017 survey, 44 per cent of students responded that tuition fees had an influence on their choice of course, but of all the surveyed factors, such as the destination and the reputation of the programme and choices of friends, tuition fees had the least impact (New Zealand University 
Students' Association [NZUSA], 2017). In another study, less than nine per cent of university students said they would consider discontinuing study if the fees were to increase by as much as 50 per cent (Baxter, 2012). Such studies suggest a somewhat limited impact of the tuition fee related barriers for existing tertiary students in the New Zealand context. However, they do not offer insights into the salience of price constraint and debt aversion related barriers for people deciding not to participate in the system in the first place.

Making tertiary education more affordable can be seen as a worthy goal given that since 2003, the average affordability of tertiary education has decreased compared to average weekly earnings in New Zealand (Ministry of Education, 2018a) and many students report significant financial distress during their studies (NZUSA, 2017). The current student funding mechanisms allow most full-time students either to borrow up to \$232 per week towards living costs (StudyLink, 2018b) or if meeting the eligibility criteria, to access the student allowance scheme. The combined student allowance and accommodation benefit maximum weekly rate for a single student under 24 years of age (after tax) and living away from home in Auckland is around \$290 per week (StudyLink, 2018a). These figures neither compare favourably with the average weekly rent for a room in Auckland (\$250), nor the average national total spending of around \$340 per week (NZUSA, 2017). Hence, whilst welcoming zero fees, the reality is that the scheme does not make everyday living any easier for the majority of students using the student loan scheme to cover their fees, and whose parent/s are not in a financial position to subsidise their living costs.

The zero-fee policy will do little to alleviate financial pressures during studies for the majority of students currently using the student loan scheme to cover their tuition fees (Ministry of Education, 2017b). The extent to which the zero-fee scheme will result in increased participation is also less clear. This is because in New Zealand and elsewhere, out of the overall costs of tertiary education, tuition fees form only a small portion compared to living costs and foregone earnings (OECD, 2017, Table A7.1a \& A7.1b; Paulsen, 2005; Usher \& Medow, 2010). Nevertheless, following the assumptions of economic theory (in the context of tuition fees c.f. Dearden, Fitzsimons, \& Wyness, 2011; Heller, 1997; Leslie \& Brinkman, 1987; Maani, 1997), the zero-fee policy can be expected to have at least a small to modest impact on the overall participation rates in the short to medium timeframe. What is important to stress is that this growth in participation does not automatically mean increased participation from the hitherto under-represented groups, those from low socio-economic backgrounds, and in the context of degree-level study, Māori and Pasifika.

\section{Zero-fee policy and participation for people from low socio-economic backgrounds, Māori and Pasifika students}

Studies from the 1980s onwards demonstrate socio-economic inequalities in tertiary education transitions and participation in New Zealand (e.g., Engler, 2010; Fergusson \& Woodward, 2000; Fergusson et al., 2008; Loader \& Dalgety, 2008; Maani, 2006; Meehan, Pacheco, \& Pushon, 2017; Ministry of Education, 1991; NZUSA, 2017; Todd Task Force, 1994; Ussher, 2007, 2008). In 1989, prior to the implementation of the user-pays policy, students from the highest parental income level backgrounds were over-represented in both polytechnics and universities (1.5-1.6), when (1) is the expected participation based on the size of the income group, and those from the lowest 
parental income group were clearly under-represented (0.4-0.7) (Todd Task Force, 1994). Unfortunately, the New Zealand tuition fee reforms in the early 1990s were not followed by comprehensive research into changes in participation for different socioeconomic status (SES) groups, and the snapshots of findings available do not allow us to establish a reliable link between tuition fee level reforms and related changes in participation for different socio-economic status groups. $^{5}$

The international evidence indicates that these types of socio-economic disparities, in one form or another, exist across the developed world, and can be neither conclusively explained by the existence nor the level of tuition fee (c.f. OECD, 2017; Usher \& Medow, 2010). For instance, in the United States the proportion of low-income students stayed the same for 20 years albeit with increasing fees (Mumper \& Freeman, 2005). Meanwhile, the Australian 1989 tuition fee reform led to significantly higher private responsibility, and even with the introduction of a deferred payment scheme did not reduce university participation from low socio-economic backgrounds (Chapman \& Ryan, 2005; James, 2000). Similarly, studies from the UK have demonstrated that a significant rise in the average tuition fee levels in 2006 and 2012 did not reduce the number of students from low socio-economic backgrounds but reduced some pertinent participation gaps (Crawford, 2012; Crawford \& Greaves, 2015; Department for Business Innovation \& Skills, 2015). In the Irish case, the 1995-1996 zero-fee reform was followed by a growth in students from many of the lower socio-economic background groups. However, the expected participation rates for students from some of the clearly under-represented groups, such as lower professional and non-manual backgrounds, remained almost static or even declined between 1998 and 2004 (O'Connell, Clansy, \& Selina, 2006, Table 3.8).

Similarly, ethnicity-based disparities are not unique to New Zealand, and have been reported in countries such as the USA, UK and Australia (Behrendt, Larkin, Griew, \& Kelly, 2012; Crawford \& Greaves, 2015; Musu-Gilette et al., 2017). In New Zealand, Māori and Pasifika students were clearly under-represented among tertiary students before the 1990s (Ministry of Education, 1991; Todd Task Force, 1994). In the first years of the user-pay policy, the Māori participation rate grew from 6 per cent of all enrolments in 1989 (compared to around 16 per cent of Māori in the 18-24 age group) to 7.6 per cent in 1991 and 9.6 percent in 1993 (Ministry of Education, 1991; Todd Task Force, 1994). Participation from both Māori and Pasifika improved during the rest of the 1990s despite the ever-increasing tuition fees (Ministry of Education, 1999, 2002, 2005).

A summary of participation rates for the decade 2006 to 2016 pointed to a decline of 3.8 per cent for Māori in the 16-64 age group, mainly as a result of lower participation in pre-degree courses coupled with a small increase at degree and post-graduate qualifications (Ministry of

\footnotetext{
${ }^{5}$ Nikula (2018) emphasises the difficulties in these types of cross-study comparisons as most New Zealand studies operationalise SES differently (e.g., school decile, parental income level, parental education level), use various sub-categorisations of the chosen SES metrics (e.g., the income or education level sub-categories used) and address distinct dimensions of higher education (e.g., whole tertiary education system versus universities or polytechnics, or all levels of study degree level only). Large differences can be also expected between studies that have controlled the SES findings for other explanatory factors, such as ethnicity or prior school achievement and studies that have only examined the link between socio-economic background and participation levels. A systematic cross-study comparison was beyond the scope of this paper.
} 
Education, 2017g, p. 9). Over the same ten years, Pasifika had a small decrease of 0.2 per cent, mainly as a result of lower participation at sub-degree levels but with an increase of 1.3 per cent in participation at degree and higher qualification levels (Ministry of Education, 2017g, p. 9).

In 2017 in the working age population, the age-standardised participation rates across tertiary institutions and qualifications were 16.4 per cent for Māori, 12.5 per cent for Pasifika, and 11 per cent for Pākehā (Ministry of Education, 2018e, Table 2). However, while Māori and Pasifika overall participation rates were higher than Pākehā, they remain under-represented at degree and higher qualification levels (Ministry of Education, 2018e, Table 3; Ministry of Education, 2017g, p.9).

Even though the evidence does not indicate a clear link between increased private responsibility and participation for Māori, Pasifika and those from low income groups, overseas studies provide some evidence that people from low socio-economic groups are more mindful of the price constraints (opportunity cost) and have a greater level of debt aversion (c.f. Callender \& Mason, 2017; Mumper \& Freeman, 2005). The current student financing facilities in New Zealand can address some aspects of these upfront financial constraints (i.e., by providing access to student loans and the availability of targeted student allowances). However, finances, such as accommodation and travel costs during study, and accumulating student debt, have been identified as concerns for New Zealand students from low socio-economic backgrounds (Webber et al., 2018). The impact of this debt aversion on actual participation and how the fees-free policy changes student perceptions warrants further research.

The many non-financial factors emphasised earlier in this paper play also a pivotal role for understanding socio-economic inequalities in participation, for instance, a family's cultural and social capital and aspirations, and many mediating factors such as pre-tertiary level educational attainment/achievement. Other factors including structural conditions such as selectivity in the higher education system (e.g., limited available pathways/accessibility) can deter participation from these low socio-economic and other under-represented groups (c.f. Asplund, Oussama, \& Skalli, 2007; Chapman \& Ryan, 2005; Chesters \& Watson, 2013; Cupitt, Costello, Eagle, \& Raciti, 2015; James, 2000, 2008; Pitman, 2017). Addressing the many cultural and social aspects is important in order to improve participation for Māori and Pasifika students as indicated in a range of studies. These include: the need to build positive links between schools and families; high expectations from teachers; early academic preparation and inspiration; guidance with secondary school subject options with clear educational pathways and support; and the importance of the right cultural 'fit' (e.g., Ako Aotearoa, 2014; Chauvel \& Rean, 2012; Madjar \& McKinley, 2014; Radloff \& Coates, 2011; Taurere, 2010; Webber et al., 2018).

The zero-fee policy may have the potential to change some perceptions of affordability for low income background students and their families, making tertiary education a more attractive option for these students. However, it does little to address the upfront living costs during studies, and due to the complexity of reasons (including an array of non-financial reasons) impacting on the decision to participate, it is unlikely that the fees-free policy will radically improve accessibility for Māori, Pasifika and low SES groups without further comprehensive interventions clearly targeted to reduce existing inequalities. 


\section{Discussion}

The zero-fee policy has the potential to enhance tertiary education participation in New Zealand. However, within the existing policy framework, significant attention needs to be placed on any future policy (non)changes in the overall tertiary education system as these can possibly offset any benefits acquired from the zero-fee policy. The new government is yet to address the question of institutional per-student funding which can have significant ramifications for participation. Insufficient institutional funding may reduce education providers' interest in offering certain programmes of study or investing in pivotal outreach and support services for non-traditional and Māori /Pasifika students.

Moreover, the new government will need to address the existing situation where New Zealand education providers are operating within a capped entry system, with some universities already having to restrict the number of new enrolments. Any increased selectivity and competition for the study places as a result of the zero-fee policy may significantly harm participation for students from low socio-economic and other under-represented groups (Jerrim, Chmielewski, \& Parker, 2015; Palmer, Bexley, \& James, 2011; Pitman, 2015). This can happen in the context of overall tertiary education accessibility or in the form of horizontal differentiation, where stratification helps privileged groups to maintain their outcomes and relative advantage (c.f. Lucas, 2001; Shavit, 2007). That is, “...the subject in which a degree is gained, as well as the institution at which it was gained, are likely to have increased in importance in the allocation of desirable occupations" (Van De Werfhorst, Sullivan, \& Cheung, 2003, p. 60). In the New Zealand context, these types of inequalities already exist when looking at Māori /Pasifika or low SES background students choosing lower qualification levels or polytechnics instead of universities (Loader \& Dalgety, 2008; Maani, 2006; Ministry of Education, 2018d; Ussher, 2007). There are also pronounced disparities in areas such as medicine and dentistry which have some of the most stringent selective admission practices and highest private premiums in the New Zealand context (Crampton, Weaver, \& Howard, 2012; Heath, Stoddart, \& Green, 2002; Marino et al., 2006; Scott, 2009). Increased selectivity could further advance these types of qualitative differences.

Finally, this paper argued that as a standalone policy, the zero-fee scheme will neither address many of the existing financial barriers nor under-representation for people from low socioeconomic and Māori /Pasifika backgrounds. Whilst removing the substantial cost of tuition fees through the zero-fee policy is laudable, this policy does little to address the upfront financial barriers such as living costs during study. To address these upfront fiscal barriers, the Government would have needed to consider more significant increases in the maximum allowance and student loan entitlements than the ones introduced in 2018. Moreover, due to the complex set of both financial and non-financial factors impacting on students' decision making, radical improvements in participation rates for under-represented groups are likely to require a change in the chosen approach. New Zealand studies have emphasised the need for interventions earlier in the education system, such as ways to lift school achievement, engagement, awareness and inspirations of under-represented students (Chauvel \& Rean, 2012; McLaughlin, 2003; Meehan et al., 2017; Webber et al., 2018; Webber, McKinley, \& Rubie-Davies, 2016) or targeted funding policies, such as 'First in Family Scholarships' (NZUSA, 2017). These types of early interventions and/or more targeted funding policies could have been more cost efficient in improving participation for the groups most likely to opt out than the chosen universal zero-fee design. 


\section{Conclusions}

The zero-fee policy represents the most significant increased generosity change in the New Zealand student funding policy trajectory since the introduction of the 'user pays' model in 1990. Other changes improving the generosity have taken place, but they have been more limited in their magnitude and/or the number of students affected (Nikula, 2015). The zero-fee policy helps reduce some of the price constraints and the debt burden for tertiary level students, but more comprehensive interventions will be necessary to address the array of reasons explaining existing disparities. This paper also warns against some of the potential adverse consequences for the currently under-represented students if the zero fee policy results in either increased selectivity or fewer support/outreach programmes targeted specifically for Māori, Pasifika, and low socioeconomic students. Hence, to support participation, Government must ensure proper funding levels for all tertiary providers.

The zero-fee policy should now be followed by a comprehensive research programme, where the role played by financial barriers is further examined and all future changes in equality and participation are carefully measured. Examination of the latter is now better enabled with the changes in the Statistics NZ Integrated Data Infrastructure allowing the establishment of links between individual students and their parents. Besides accessibility, the research agenda should include success/retention and equality of outcomes in a longitudinal research design addressing diverse sources of potential socio-economic and ethnic inequalities. Special attention should be placed on qualitative disparities, such as the level of study or the subject area chosen, to understand more clearly educational reproduction in the $21^{\text {st }}$ century compared to more macro level approaches.

\section{References}

Ako Aotearoa. (2014). Success in tertiary education for Pacifica: Highlights from Ako Aotearoasupported research. Ako Aotearoa. Retrieved from https://ako.ac.nz/assets/reports/ Synthesis-reports/3d6994ffce/SYNTHESIS-REPORT-Success-for-Pasifika-in-tertiaryeducation-Highlights-from-Ako-Aotearoa-supported-research.pdf

Asplund, R., Oussama, B.-A., \& Skalli, A. (2007). An equity perspective on access to, enrolment in and finance of tertiary education (ETLA Discussion Papers, No. 1098). Helsinki: The Research Institute of the Finnish Economy (ETLA).

Baxter, R. (2012). Sharing the private and public costs of tertiary education. Policy Quarterly, 8(2), 48-53. doi.org/10.26686/pq.v8i2.4419

Behrendt, L., Larkin, S., Griew, R., \& Kelly, P. (2012). Review of higher education access and outcomes for Aboriginal and Torres Strait Islander people: Final report. Australian Government. Retrieved from http://docs.education.gov.au/node/36825

Boudon, R. (1974). Education, opportunity, and social inequality. New York: Wiley.

Bourdieu, P., \& Passeron, J. C. (1977). Reproduction in education, society and culture. London: Sage.

Butterworth, R., \& Tarling, N. (1994). A shakeup anyway: Government and the universities in New Zealand in a decade of reform. Auckland: Auckland University Press. 
Callender, C., \& Mason, G. (2017). Does student loan debt deter higher education participation? New evidence from England. The ANNALS of the American Academy of Political and Social Science, 671(1), 20-48. doi.org/10.1177/0002716217696041

Chapman, B., \& Ryan, C. (2005). The access implications of income-contingent charges for higher education: Lessons from Australia. Economics of Education Review, 24(5), 491512. doi.org/10.1016/j.econedurev.2004.08.009

Chauvel, F., \& Rean, J. (2012). Doing better for Māori in tertiary settings: Review of the literature. Wellington: Tertiary Education Commission.

Chesters, J., \& Watson, L. (2013). Understanding the persistence of inequality in higher education: Evidence from Australia. Journal of Education Policy, 28(2), 198-215. doi.org/10.1080/02680939.2012.694481

Collins, C. (2017, November 11). Mid-life adults join teens in rush for free tertiary education. New Zealand Herald. Retrieved from https://www.nzherald.co.nz/nz/news/article.cfm?c_ id $=1$ \&objectid $=11942988$

Crampton, P., Weaver, N., \& Howard, A. (2012). Holding a mirror to society? The sociodemographic characteristics of the University of Otago's health professional students. The New Zealand Medical Journal, 125(1361), 12-28.

Crawford, C. (2012). Socio-economic gaps in HE participation: How have they changed over time? (IFS Briefing Note BN133). Institute for Fiscal Studies. Retrieved from http://sticerd.Ise.ac.uk/dps/case/spcc/RN08CCPres.pdf

Crawford, C., \& Greaves, E. (2015). Socio-economic, ethnic and gender differences in HE participation (BIS RESEARCH PAPER NO.186). UK: Department for Business, Innovation and Skills. Retrieved from http://dera.ioe.ac.uk/id/eprint/24685

Crawford, R. (2016). History of tertiary education reforms in New Zealand. New Zealand Productivity Commission. Retrieved from https://www.productivity.govt.nz/workingpaper/history-of-tertiary-education-reforms-in-new-zealand

Cupitt, C., Costello, D., Eagle, L., \& Raciti, M. (2015). Social marketing strategy for promoting tertiary education to low SES communities (Position paper). Widening Participation Service Design. Retrieved from https://www.ncsehe.edu.au/wp-content/uploads/ 2016/10/Final-SM-Position-Paper_ACCESSIBLE.pdf

Dearden, L., Fitzsimons, E., \& Wyness, G. (2011). The impact of tuition fees and support on university participation in the UK. London: Centre for the Economics of Education, London School of Economics. Retrieved from http://cee.Ise.ac.uk/ceedps/ceedp126.pdf

Department for Business, Innovation \& Skills. (2015). Student finance equality analysis: The Education (Student Support) (Amendment) Regulations 2015. London: Author. Retrieved from https://www.gov.uk/government/uploads/system/uploads/attachment_data/ file/482110/bis-15-639-student-finance-equality-analysis.pdf

Engler, R. (2010). School leavers' progression to bachelors-level study. Wellington, NZ: Ministry of Education.

Fergusson, D. M., \& Woodward, L. J. (2000). Family socio-economic status at birth and rates of university participation. New Zealand Journal of Educational Studies, 35(1), 25-36.

Fergusson, D. M., Horwood, L., \& Boden, J. (2008). The transmission of social inequality: Examination of the linkages between family socio-economic status in children and 
education achievement in young adulthood. Research in Social Stratification and Mobility, 26, 277-295. doi.org/10.1016/j.rssm.2008.05.001

Gerritsen, J. (2018, February 23). Little benefit from zero-fee policy: Universities. Radio New Zealand. Retrieved from http://www.radionz.co.nz/news/national/351136/littlebenefit-from-zero-fee-policy-universities

Harding, E. (2018, May 1). SIT student numbers down. Stuff News. Retrieved from https://www.stuff.co.nz/national/103493855/sit-student-numbers-down

Heath, C., Stoddart, C., \& Green, H. (2002). Parental backgrounds of Otago medical students. The New Zealand Medical Journal, 115(1165), U237.

Heller, D. E. (1997). Student price response in higher education. The Journal of Higher Education, 68(6), 624-659. doi.org/10.1080/00221546.1997.11779004

Higgins, J., Vaughan, K., Phillips, H., \& Dalziel, P. (2008). Education employment linkages: International literature review (EEL Research Report No.2). Retrieved from www.nzcer.org.nz/system/files/EELReport02.pdf

Institute of Public Administration New Zealand. (2018). Deloitte IPANZ Public Sector Excellence Awards. Retrieved from https://ipanz.org.nz/Attachment?Action=Download\&Attachment_id=150245

James, R. (2000). Socio-economic background and higher education participation: An analysis of school students' aspirations and expectations. Canberra: Department of Education, Science and Training.

James, R. (2001). Participation disadvantage in Australian higher education: An analysis of some effects of geographical location and socio-economic status. Higher Education, 42(4), 455-472. doi.org/10.1023/A:1012264010667

James, R. (2008). Achieving social inclusion and universal participation: Towards new conceptions of higher education. New Zealand Annual Review of Education (Online), 18, 47-63.

Jerrim, J., Chmielewski, A. K., \& Parker, P. (2015). Socio-economic inequality in access to highstatus colleges: A cross-country comparison. Research in Social Stratification and Mobility, 42, 20-32. doi.org/10.1016/j.rssm.2015.06.003

Jones, N. (2018, February 22). "Grossly inequitable" fees-free warning from universities. New Zealand Herald. Retrieved from https://www.nzherald.co.nz/nz/news/article.cfm?c_id=1\&objectid $=11999085$

Kelsey, J. (1995). The New Zealand experiment: A world model for structural adjustment? Auckland: Auckland University Press.

Labour Party. (n.d.). Making tertiary education and training affordable for all. Retrieved from http://www.labour.org.nz/tertiaryeducation

Labour Party. (2016). The future of work (Policy document). Labour Party.

Leach, L., \& Zepke, N. (2005). Student decision-making by prospective tertiary students: A review of existing New Zealand and overseas literature. Wellington: Ministry of Education.

Leslie, L. L., \& Brinkman, P. T. (1987). Student price response in higher education. The Journal of Higher Education, 58(2), 181-204. doi.org/10.1080/00221546.1987.11778239

Loader, M., \& Dalgety, J. (2008). Students' transition between school and tertiary education ( $2^{\text {nd }}$ ed.). Wellington, NZ: Ministry of Education. 
Lucas, S. R. (2001). Effectively maintained inequality: Education transitions, track mobility, and social background effects. American Journal of Sociology, 106(6), 1642-1690. doi.org/10.1086/321300

Maani, S. A. (1997). Investing in minds: The economics of higher education in New Zealand. Wellington, NZ: Institute of Policy Studies.

Maani, S. (2006). Parental income and the choice of participation in university, polytechnic, or employment at age 18: A longitudinal study. In J. Creedy \& G. Kalb (Eds.), Dynamics of inequality and poverty (vol. 13, pp. 217-248). Bingley: Emerald.

Madjar, I., \& McKinley, E. (2014). From schools in low-income communities to university: Challenges of transition for Māori and Pacific students. In F. Cram, H. Phillips, P. Sauni, \& C. Tuagalu (Eds.), Māori and Pasifika higher education horizons (Vol. 15, pp. 241-252). Emerald. https://doi.org/10.1108/S1479-364420140000015020

Marino, R. J., Morgan, M. V., Winning, T., Thomson, M. W., Marshall, R. I., Gotjamanos, T., \& Evans, W. (2006). Sociodemographic backgrounds and career decisions of Australian and New Zealand dental students. Journal of Dental Education, 70(2), 169-178.

McLaughlin, M. (2003). Tertiary education policy in New Zealand. Fulbright Centre. Retrieved from https://www.fulbright.org.nz/wpcontent/uploads/2011/12/axford2002_mclaughlin.pdf

Meehan, L., Pacheco, G., \& Pushon, Z. (2017). Explaining ethnic disparities in bachelor's qualifications: Participation, retention and completion in New Zealand. New Zealand Productivity Commission. Retrieved from https://www.productivity.govt.nz/sites/ default/files/Meehan\%20Pacheco\%20Pushon\%20working\%20paper\%209\%20Feb\%2020 17.pdf

Ministry of Education. (1991). Reports of the Tertiary Review Group. Wellington: Author. Ministry of Education. (1999). Profile \& trends 1998: New Zealand's tertiary education sector. Wellington: Author.

Ministry of Education. (2002). Ngā Haeata Mātauranga: Annual report on Māori Education 2000/01 and direction for 2002. Wellington: Author.

Ministry of Education. (2005). Māori participation in tertiary education: 2004. Ministry of Education. Retrieved from Retrieved from https://www.educationcounts.govt.nz/ publications/series/5851/5855

Ministry of Education. (2008). Student loan scheme annual report. Wellington: Author. Ministry of Education. (2009a). Profile \& trends 2008: New Zealand's tertiary education sector. Wellington: Author.

Ministry of Education. (2009b). Policy options for new student contributions in higher education: Report to Minister for Education and Science. Ireland: Ministry of Education. Retrieved from

http://www.education.ie/servlet/blobservlet/he_2009_fees_report.pdf?language=EN Ministry of Education. (2017a, December 6). Education report: Final financial implications for the '100 days' tertiary education commitments. Retrieved from http://www.education.govt.nz/ministry-of-education/information-releases/informationreleases-from-past-years/100-days/

Ministry of Education. (2017b). Student loan scheme annual report. Wellington: Author. 
Ministry of Education. (2017c, November 20). How many students may be affected by a feesfree $\$$ value cap? Retrieved from http://www.education.govt.nz/ministry-ofeducation/information-releases/information-releases-from-past-years/100-days/

Ministry of Education. (2017d, November 20). Initial decisions to support making tertiary education and training affordable for all (Cabinet paper). Retrieved from http://www.education.govt.nz/ministry-of-education/information-releases/informationreleases-from-past-years/100-days/

Ministry of Education. (2017e, November 23). Education report: Finalising your draft Cabinet paper: Making tertiary education more affordable: Fees free education in 2018. Retrieved from http://www.education.govt.nz/ministry-of-education/informationreleases/information-releases-from-past-years/100-days/

Ministry of Education. (2017f, December 4). Making tertiary education more affordable: Feesfree education in 2018. Retrieved from http://www.education.govt.nz/ministry-ofeducation/information-releases/information-releases-from-past-years/100-days/

Ministry of Education (2017g). Profile \& trends 2016: New Zealand's annual tertiary education enrolments. Wellington: Author.

Ministry of Education. (2018a). Affordability of tertiary education. Retrieved from https://www.educationcounts.govt.nz/statistics/indicators/main/family-andcommunity-engagement/1999

Ministry of Education. (2018b). Financial resources. Retrieved from https://www.educationcounts.govt.nz/statistics/tertiary-education/resources

Ministry of Education. (2018c). Participation rates. Retrieved from https://www.educationcounts.govt.nz/statistics/tertiary-education/participation

Ministry of Education. (2018d). Profile \& trends 2017: New Zealand's tertiary education sector. Retrieved from https://www.educationcounts.govt.nz/publications/tertiary

Ministry of Education (2018e). Participation rates in tertiary education: Data tables. Retrieved from https://www.educationcounts.govt.nz/_data/assets/excel_doc/0010/107974/ inID-1963-datatablesii.xIsx

Ministry of Social Development. (n.d.). Student allowances. Retrieved from https://www.studylink.govt.nz/products/a-z-products/student-allowance/index.html\#null

Mumper, M., \& Freeman, M. L. (2005). The causes and consequences of public college tuition inflation. In J. C. Smart (Ed.), Higher education: Handbook of theory and research (Vol. XX, pp. 307-362). Dordrecht: Springer.

Musu-Gilette, L., de Brey, C., McFarland, J., Hussan, W., Sonnenberg, W., \& Wilkinson-Flicker, S. (2017). Status and trends in the education of racial and ethnic groups 2017. Washington, DC: National Center for Education Statistics US.

Nikula, P.-T. (2015). Expansion and contraction in student funding policies: A cross-country study of higher education cost-sharing reforms in Finland and New Zealand (Doctoral diss.). The University of Auckland, Auckland, NZ.

Nikula, P.-T. (2018). Socio-economic inequalities in higher education: A meta-method analysis of twenty-first century studies in Finland and New Zealand. Studies in Higher Education, 43(12), 2305-2320.NZUSA. (2017). Income and expenditure report 2017. Retrieved from http://www.students.org.nz/studentreport 
O'Connell, P. J., Clansy, D., \& Selina, M. (2006). Who went to college in 2004? A national survey of new entrants to higher education. Dublin: Higher Education Authority.

OECD. (2009). Education at a glance 2009: OECD Indicators. Paris: Author.

OECD. (2017). Education at a glance 2017: OECD indicators. Paris: Author.

Palmer, N., Bexley, E., \& James, R. (2011). Selection and participation in higher education: University selection in support of student success and diversity of participation. Centre for the Study of Higher Education. Retrieved from https://melbournecshe.unimelb.edu.au/_data/assets/pdf _file/0004/1490980/Selection_and_Participation_in_Higher_Education.pdf

Paulsen, M. B. (2005). The economics of the public sector. In J. C. Smart (Ed.), Higher education: Handbook of theory and research (Vol. XX, pp. 95-132). Dordrecht, Netherlands: Springer.

Perna, L. W. (2010). Toward a more complete understanding of the role of financial aid in promoting college enrollment: The importance of context. In J. C. Smart (Ed.), Higher education: Handbook of theory and research (pp. 129-179). Dordrecht, Netherlands: Springer. doi.org/10.1007/978-90-481-8598-6_4

Pitman, T. (2015). Unlocking the gates to the peasants: Are policies of 'fairness' or 'inclusion' more important for equity in higher education? Cambridge Journal of Education, 45(2), 281-293. doi.org/10.1080/0305764X.2014.970514

Pitman, T. (2017). Widening participation in higher education: A play in five acts. Australian Universities' Review, 59(1), 37-46.

Radloff, A., \& Coates, H. (ACER), (2011). Student engagement in New Zealand's universities. Wellington: Ako Aotearoa.

Scott, D. (2009). What do students earn after their tertiary education? Wellington: Statistics New Zealand.

Shavit, Y. (2007). Stratification in higher education : A comparative study. Stanford, CA: Stanford University Press.

Small, V., Kirk, S., \& Cooke, H. (2017, August 29). Big boost for education, tertiary study as Labour unveils spending plan. Stuff News. Retrieved from https://www.stuff.co.nz/national/politics/96252388/

big-boost-for-education-tertiary-study-as-labour-unveils-spending-plan

Smart, W. (2009). Ebbs and flows: Participation in post-compulsory education over the economic cycle. Ministry of Education. Retrieved from https://www.educationcounts.govt.nz/ data/assets/pdf_file/0011/49259/Ebbs-and-flows.pdf

Starke, P. (2008). Radical welfare state retrenchment. A comparative analysis. Hampshire: Palgrave Macmillan.

StudyLink. (2018a). Student allowance rates. Retrieved from https://www.studylink.govt.nz/products/rates/student-allowance-rates.html

StudyLink. (2018b). Student loan living costs. Retrieved from https://www.studylink.govt.nz/ products/a-z-products/student-loan/living-costs.html\#null

Taurere, M. (2010). Advocates for Māori students: The role of career advisors? (Doctoral diss.). University of Auckland, NZ.

Tertiary Education Commission. (2014). Information for learners: Learner decision-making behaviours: Research summary. Wellington, NZ: Author. 
Tertiary Education Commission. (2018a). Fees free: What tertiary education organisations need to know. Retrieved from http://www.tec.govt.nz/fees-free-what-tertiary-educationorganisations-need-to-know

Tertiary Education Commission. (2018b). What are the eligibility criteria? Retrieved, from www.feesfree.govt.nz/faqs/

Todd Task Force. (1994). Funding growth in tertiary education and training: Report of the Ministerial Consultative Group. Wellington: Ministry of Education.

Usher, A. (2006). Grants for students: What they do, why they work. Toronto: Educational Policy Institute.

Usher, A., \& Medow, J. (2010). Global higher education rankings 2010: Affordability and accessibility in comparative perspective. Higher Education Strategy Associates. Retrieved from https://higheredstrategy.com/wp-content/uploads/2011/09/GHER2010_FINAL.pdf.

Ussher, S. (2007). Tertiary education choices of school leavers. Wellington: Ministry of Education $\mathrm{NZ}$.

Ussher, S. (2008). Post-school choices: How well does academic achievement predict the tertiary education choices of school leavers? Wellington: Ministry of Education.

Van De Werfhorst, H. G., Sullivan, A., \& Cheung, S. Y. (2003). Social class, ability and choice of subject in secondary and tertiary education in Britain. British Educational Research Journal, 29(1), 41-62. doi.org/10.1080/0141192032000057366

Webber, M., Eaton, J., Cockle, V., Linley-Richardson, T., Rangi, M., \& O’Connor, K. (2018). Starpath phase three: Final Report. Auckland: Starpath Project, The University of Auckland.

Webber, M., McKinley, E., \& Rubie-Davies, C. M. (2016). Making it personal: Academic counseling with Māori students and their families. Contemporary Educational Psychology, 47, 51-60.

Zero-fees: "That hypothetical student doesn't exist." (2018, June 25). Radio New Zealand. Retrieved from http://www.radionz.co.nz/national/programmes/ninetonoon/ audio/2018650766/zero-fees-that-hypothetical-student-doesn-t-exist

Dr Pii-Tuulia Nikula lectures at the Eastern Institute of Technology. One of Pii-Tuulia's key research areas focuses on student funding and educational equality within tertiary education and pertinent policy frameworks. In her PhD research at the University of Auckland, Pii-Tuulia examined the historical development of tuition fee and other student funding policies in New Zealand and Finland.

Email: pnikula@eit.ac.nz

ORCID: 0000-0002-6683-2964

Kay Morris Matthews is Research Professor, Faculty of Education, Humanities and Health Sciences at the Eastern Institute of Technology. Her research in education across 30 years spans educational policy, higher education, history of education and gender education.

Email: KMorris@eit.ac.nz

NO ORCID 